\title{
Knowledge Management of Agricultural Prophecy in the Manuscript of Sundanese Society in Tasikmalaya District of West Java Indonesia
}

\author{
Nuning Kurniasih \\ Library and Information Science Program, Faculty of Communication Science \\ Universitas Padjadjaran \\ Bandung, Indonesia \\ nuning.kurniasih@unpad.ac.id
}

\begin{abstract}
Although most people have left behind the traditional prophecy in this modern era, there are few circles that still belief it and actually using it. In the field of agriculture some farmers still believe in the traditional prophecy regards the weather forecast even though there is modern calculation. This study aims to understand how the knowledge management of agricultural prophecy in the manuscripts of Sundanese society. The study is based on qualitative approach with ethnographic methods. Data collection incorporates participant-observation, interviews, and literature study. The results show the ancestors passed down the knowledge, values, and ability orally and supported it with text Unfortunately, the original manuscript had not been passed down; Hanacaraka methods include letters related to values and direction in accordance with the letters, years, months and days count, forbidden months, forbidden directions/ stay away from danger, bad luck months, good direction to pass through during a certain day; the informant claims that every day is a good day, but we need to choose the best day among these good days, with Hanacaraka Methods; the informant obtained the Hanacaraka prophecy method orally and supported by manuscript text, which has to be copied and handwritten by himself from his ancestor's manuscript. The result of the study might generate contribution for the government in maintaining local wisdom or indigenous knowledge by preserving the traditional intellectual asset of individuals in a society.
\end{abstract}

Keywords - knowledge management; traditional knowledge management, agricultural prophecy, Sundanese, manuscripts

\section{INTRODUCTION}

Ancient manuscript is a cultural document consists of various data, information, notions, feelings, knowledge, histories, and culture of a tribe or a social group [1] [2]. This ancient manuscript depicts civilization heritage or valuable information of various life aspects in the past, such as letters, agreements, genealogies, histories, ceremonies, rules, procedures, folklores, fairytales, legends, prophecies, etc. Many ancient documents in the form of manuscripts currently belong to individuals. Some individuals inherit the original manuscripts to their descendants or their trusted people, and the other some only inherit the values or information inside the manuscripts without handing over the original manuscripts.
One of the contents in Sundanese manuscripts is regarding the prophecy. Prophecy used to strongly connect to Sundanese society's everyday life. For example, the ancestors of Sundanese usually made use of paririmbon (a Sundanese manuscript) as daily practices guidance. Pranatamangsa inscription in Indrayasa village of Kawali sub-district in Ciamis district of West Java Indonesia is one of the inscriptions describing the use of paririmbon since the ancient times [1]. This Paririmbon contains a calendar, guidance to give names to the newborn baby, prophecies regarding one's characters and fate based on his day of birth and physical traits, spouses' compatibility, how to determine good dates to held a big event, such as wedding day and house moving day, how to determine the good direction to make a living, prophecy regards the missing goods, agricultural calculation, etc.

Although most people have left behind the traditional prophecy in this modern era, there are few circles that still belief it and actually using it. For instance, in the field of agriculture some farmers still believe in the traditional prophecy regards the weather forecast even though there is modern calculation regarding the matter from Indonesian Agency of Meteorological, Climatological, and Geophysics. Some farmers in Tasikmalaya district usually meet a certain person who believed to be able to predict or calculate the good dates to farming. They assume the calculation or prophecy of the good dates will yield better harvest than farming without following the prophecy. The informant for this study is one of the believed persons that the farmers come to meet every time they need for good dates prophecy to farming in Tasikmalaya. The knowledge and ability to tell fortune were obtained hereditary from his ancestors. The informant admits telling fortune based on the Hanacaraka methods.

Historically, Hanacaraka is the new Java script developed from the ancient Java script named Pallawa. Hanacaraka script is a media to express taste, creation, and intention in form of text by using symbols of the sound system of basic (legena) script and vocal script, and is also syllabic or consists of syllables. The originator of Hanacaraka script is the king of Medangkamulan, which identical with the Kingdom of Mataram Kuna. The Hanacaraka script then spread to Sunda, Java, Cirebon, Madura 
and Bali [3]. Sri Sultan Hamungkubuwono X in Rochyatmo [3] claims that Hanacaraka contains of life text, which including various symbolic and philosophic meanings regards the Javanese local doctrine "Eling-sangkan paraning dumadi" means remember life origins and goals.

This study aims to understand how the knowledge management of agricultural prophecy in the manuscripts of Sundanese society. The research questions include: (1) How did the informant obtain the knowledge and ability to make the agricultural prophecy? (2) What are the prophecy contents of the manuscript inherited from the ancestors to the informant? (3) Why is the method used to determine good dates for farming day is the Hanacaraka methods? (4) How does the informant pass down his knowledge and ability to his heir?

Knowledge management is a process to maintain and establish individual's asset (knowledge), which is possible to pass down easily to the others in order to improve someone's or an organization's performance [4]. The result of the study might generate contribution for the government in maintaining local wisdom or indigenous knowledge by preserving the traditional intellectual asset of individuals in a society.

\section{RESEARCH METHOD}

The study is based on qualitative approach with ethnographic methods. Ethnography study accounts a certain culture including its customs, belief, and behaviors based on data from the field [5]. In this study, researcher wants to observe how Sundanese society in Tasikmalaya takes part in maintaining knowledge regards the agricultural prophecy from the manuscript they obtain from their ancestor's generation to generation. By employing ethnography researcher attempts to seek for the social meaning of the society's or community's customs [6].

Data collection incorporates participant-observation, interviews, and literature study. Participant-observation means researcher attempts to be the part of the society in order to observe the research object directly while in-depth interview was done with an informant who has the ability to predict the good dates as farming day using the Hanacaraka methods. The informant is the one whom people always come to when they need prophecy regards the good dates to farming in Tasikmalaya, West Java of Indonesian. Data triangulation includes: (1) data and methods triangulation by interviewing the other person whom believed to be able to determine good dates to held many kinds of special events and doing observation; (2) theory triangulation by doing literature study related to the research object. Data analysis includes data and information synthesis obtained from the observation, interviews, and literature study. The interpretation in ethnography study is done to obtain meaning, pattern, and the linkages of each element found in the research process [7]. The study was done from November 2016 to June 2017.

\section{RESULTS AND DISCUSSION}

1. Origin of Knowledge and Ability to Generate Prophecy Obtained by the Informant

The key informant has notes as his guidance, which obtained from his uncle in 1982, to generate prophecy using the Hanacaraka methods. His uncle obtained it from his grandfather, and his grandfather from his great grandfather, and so on. His ancestors passed down the knowledge, values, and ability uniquely, which by giving it to the trusted ones that shows interest in the matter or to people who need it. His ancestors passed down the knowledge, values, and ability to the heirs by showing the manuscript contents and asking them to copy it only by hand writing, not allowed to type it. Then, his ancestors will explain the meaning and know-how of using the copied manuscript. His ancestors did not pass down the original manuscript itself. Thus, the heirs have their own hand written copied manuscript. The text itself has been translated into Latin letters instead of Hanacaraka letters. As we know, Indonesian has been growing with a strong oral culture. Therefore, the culture heritage mostly had been passed down only orally.

In this case, the ancestors passed down the knowledge, values, and ability orally and supported it with text. Unfortunately, the original manuscript had not been passed down. Nevertheless, the Sundanese society still has strong believe towards the agricultural prophecy, which based on the traditional knowledge rooted in their life. Pant and Morthy [8] account that traditional knowledge is the knowledge yielded from time to time through process of learning and sharing in a society or a community. Traditional knowledge plays significant role in sustainable development of indigenous community.

\section{The Manuscript Contents Passed Down by the Ancestors to the Informant}

Sundanese society has known the astronomy world, or in Sundanese called palintangan, since long time ago. For instance, there is time setting in palintangan as the guidance to calculate the good dates as farming day. In this case, farmers predict the farming time based on the nature's phenomenon or symptoms. It is based on the three principles of Sundanese to always keep the balance of nature, biological, and human [9]. Meanwhile, Daldjoeni [10] accounts that Sundanese calendar (Kala Sunda) reflected the significant relation among the aspect of cosmographical, bio climatological, and sociological on the agriculture activity in rural area, which generates dialog between human and the surrounding nature.

The calculation or prediction of agriculture and how to cure the diseased plants are also mentioned in Sundanese paririmbon [1]. Meanwhile, the notes owned by the key informant regard the agricultural prophecy using Hanacaraka methods include: (a) letters related to values and direction in accordance with the letters; (b) years count (or in Sundanese called naktu tahun); months count (naktu bulan); (c) forbidden months (the months when forbid to hold events, something will hinder it when an event held during that months); (d) forbidden directions / stay away from danger (kala gede ngagegesna); (e) bad luck months; (f) days count; (g) good direction to pass through during a certain day. Briefly, these notes might be concluded in the table 1- 6 as follows:

Table 1 Letters Related to Value and Direction

\begin{tabular}{|l|l|}
\hline Ha 1; Na 2; Ca 3; Ra 4; Ka 5; & Wetan (East) \\
\hline Da 6; Ta 7; Sa 8; Wa 9; La 10; & Kidul (South) \\
\hline Pa 11; Dha 12; Ja 13; Ya 14; Nya 15; & Kulon (West) \\
\hline Ma 16; Ga 17; Ba 18; Ta 19; Nga 20 & Kaler (north) \\
\hline
\end{tabular}


Table 2 Years and Months Count (Naktu Tahun \& Naktu Bulan)

\begin{tabular}{|c|r|r|c|r|r|}
\hline & $\begin{array}{c}\text { Nak } \\
\text { Tahun }\end{array}$ & $\begin{array}{c}\text { Manis } \\
\text { Pahing }\end{array}$ & & $\begin{array}{c}\text { Naktu } \\
\text { Bulan }\end{array}$ & Dawuh \\
\hline Alif & 1 & 5 & Muharam & 7 & 5 \\
\hline He & 5 & 9 & Safar & 2 & 5 \\
\hline Jim Awal & 3 & 4 & Maulud & 3 & 4 \\
\hline Je & 7 & 3 & S II & 5 & 3 \\
\hline Dal & 4 & 2 & J Awal & 6 & 3 \\
\hline Be & 2 & 7 & J Akhir & 1 & 2 \\
\hline Wau & 6 & 1 & Rajab & 2 & 2 \\
\hline Jim Akhir & 3 & 5 & Reuwah & 4 & 1 \\
\hline & & & Puasa & 5 & 5 \\
\hline & & & Sawal & 7 & 5 \\
\hline & & & Hapit & 1 & 3 \\
\hline
\end{tabular}

Table 3 Days Count (Naktu Poe)

\begin{tabular}{|cc|c|}
\hline Naktu Poe & & Manis Pahing \\
\hline Rebo (Wednesday) & 7 & Kaliwon 8 \\
\hline Kemis (Thursday) & 8 & Manis 5 \\
\hline Jumaah (Friday) & 6 & Pahing 9 \\
\hline Sabtu (Saturday) & 9 & Paw 7 \\
\hline Ahad (Sunday) & 5 & Wage 4 \\
\hline Senen (Monday) & 4 & \\
\hline Salasa (Tuesday) & 3 & \\
\hline
\end{tabular}

Table 4 Directions and Frobidden Directions

\begin{tabular}{|c|c|c|}
\hline Nagara Poe & & Forbidden Directions \\
\hline Muharam & & Rebo Kulon (Wednesday, West) \\
\hline Safar & & Kemis Wetan Kidul (Thursday, East South) \\
\hline Maulud & $\begin{array}{l}\text { Wetan } \\
\text { (East) }\end{array}$ & Jumaah Kaler (Friday, North) \\
\hline Silih Mulud & & Saptu Kidul (Saturday, South) \\
\hline J Awal & & Ahad Kaler Wetan (Sunday North East) \\
\hline J Akhir & $\begin{array}{c}\text { Kidul } \\
\text { (South) }\end{array}$ & Senen Kulon Kaler (Monday West North) \\
\hline Rajab & & Salasa Kulon Kidul (Tuesday West South) \\
\hline \multicolumn{3}{|l|}{ Reuwah } \\
\hline Puasa & $\begin{array}{l}\text { Kulon } \\
\text { (West) }\end{array}$ & \\
\hline \multicolumn{3}{|l|}{ Syawal } \\
\hline \multicolumn{3}{|l|}{ Hafit } \\
\hline Rayagung & Kaler & \\
\hline
\end{tabular}

Table 5 Forbidden Months (Larangan Bulan)

\begin{tabular}{|c|c|}
\hline Larangan Bulan & Rahayuna \\
\hline Muharam & Saptu, Rebo (Saturday, Wednesday) \\
\hline Safar & Ahad, Kemis (Sunday, Thursday) \\
\hline Maulud & Senen, Jumat (Monday, Friday) \\
\hline S II & Salasa, Saptu (Tuesday, Saturday) \\
\hline J Awal & Rebo, Saptu (Wednesday, Saturday) \\
\hline J Akhir & Kemis Ahad (Thursday, Sunday) \\
\hline Rajab & \\
\hline Reuwah & \\
\hline Puasa & Jumat, Senen, Salasa (Friday, Monday, Tesday) \\
\hline Syawal & \\
\hline Hapit & \\
\hline Rayagung &
\end{tabular}

Table 6 Bad Luck Months (Bulan Naas)

\begin{tabular}{|c|c|}
\hline Rampaya & 11-14 Muharam \\
\hline Parhana & 1-20 Sapar \\
\hline Dudlanga & $10-15$ Mulud \\
\hline Dudlanga & $10-12$ S II \\
\hline Walapa & $10-11$ J Awal \\
\hline Kulaya & $10-15$ J Akhir \\
\hline Jabdaya & 6-13 Rajab \\
\hline Bantonga & 10-20 Rewah \\
\hline Sawang & 9-20 Puasa \\
\hline Walanga & 10-20 Syawal \\
\hline Pitnada & 2-6 Hapit \\
\hline Gungdonga & 6-20 Rayagung \\
\hline
\end{tabular}

Source: Table 1-6 from The Contents of The Informant's

Manuscripts (belong to Mang Ihin) [11]

As seen in the Table 1-6, the prophecy calculation of Sundanese people has strong correlation with Arabic letters. No wonder, since Sundanese people known to be religious society, which always employs spirituality values in their daily activities. On the other hand, this society also still holds dearly the inherited customs from their ancestors that passed down from generation to generation, includes how to determine good dates as farming day. The frequent question asked by the farmers to the informant regarding the good dates to sow, to weed out, and to harvest rice, palawija, trees and other plants.

\section{The Reason of Using Hanacaraka Prophecy Methods in Determining the Good Dates as Farming Day}

The informant claims that every day is a good day, but we need to choose the best day among these good days. For instance, the farmers can choose the day by counting the best day using the Hanacaraka methods when about to farming. However, the result of Hanacaraka method will be not used absolutely since they still have to consider the weather condition that day. When the weather is not good then the result of days counting will not be used. They will use the good month prediction instead. The society believes that they will yield optimal harvest as long as they follow the prophecy result.

\section{How the Informant Pass Down Agricultural Prophecy Knowledge and Ability to the Heirs}

In the meantime, the key informant has not been passing down his ability to other person yet. He claims that if there is anyone who interests in or needs it then he will pass down his knowledge and ability with the same method he got it from his ancestor. This method includes make hand writing copy of the manuscript he owned then followed by the explanation of the whole procedures or how to use the manuscript.

There are at least four important elements in the process of knowledge management, which are knowledge creation, knowledge storage, knowledge transfer, and knowledge application [12]. The knowledge creation of agricultural prophecy can be initiated by compiling various information regard agricultural prophecy from the society, then documenting it. The documents can be stored in various forms depend on the technology advancement. The stored culture documents will facilitate the knowledge transfer process. Furthermore, this stored knowledge can be used as the foundation of culture-based development and to build civilized human. This might be 
working as long as there is cooperation amongst the whole elements of society and government.

\section{CONCLUSION}

Some of Sundanese society still uses the traditional way of agricultural prophecy. People usually meet certain person whom believed to have the ability to generate prophecy regards the good dates as farming day in order to yield optimal harvest. This certain person usually inherits the ability from his ancestors generation to generation. The informant obtained the Hanacaraka prophecy method orally and supported by manuscript text, which has to be copied and handwritten by himself from his ancestor's manuscript. Government and the society can work together to maintain cultural heritage by following the knowledge management stages. By managing traditional knowledge it might help in developing culture-based development and civilized society.

\section{ACKNOWLEDGMENT}

It is an independent study with the help of the informant (Mang Ihin) and expert on the field. I would like to thank to Faculty of Communication Science Universitas Padjadjaran and all of those involved for the support.

\section{REFERENCES}

[1] U. A. D. A. E. T. W. Emon Suryaatmana. Paririmbon Sunda (Jawa Barat). Jakarta: Departemen Pendidikan dan Kebudayaan RI, 1992.

[2] T. Munawar and N. Nugraha. "Khasanah naskah nusantara." in Tradisi tulis nusantara: kumpulan makalah simposium tradisi tulis Indonesia 46 Juni 1996, Jakarta, Masyarakat Pernaskahan Nusantara, 1997.
[3] A. Rochkyatmo. Pelestarian dan modernisasi aksara daerah: perkembangan metode dan teknis menulis aksara Jawa. Jakarta: Departemen Pendidikan dan Kebudayaan RI, 1996.

[4] A. Brooking. Corporate memory: strategies for knowledge management. London: International Thomson Business Press, 1999.

[5] M. Harris and O. Johnson. Cultural anthropology, $5^{\text {th }}$ ed. Needham Heights, MA: Allyn and Bacon, 2000.

[6] J. D. Brewer. Ethnography. Buckingham · Philadelphia: Open University Press, 2000.

[7] M. Genzuk. "A Shynthesis of ethnographic research. occasional paper series." Center for Multilingual, Multicultural Research (Eds.) Rossier School of Education, University of Southern California , Los Angeles, 2003

[8] A. Pant and A. Morthy. "Knowledge management and safeguarding indian tradition knowledge." Annals of Library and Information Studies, Vol. 60, pp. 88-97, 2013.

[9] R. Agam, "Tradisi palintangan ala Sunda." Media Indonesia (Sept, 2010), pp. 20, 25

[10] N. Daldjoeni. "Pranatamangsa, the Javanese agricultural calendar-its bioclimatological and sociocultural function in developing rural life," Enviromentalist, Vol. 4, Supplement 7, pp. 15-18, 1984.

[11] Mang Ihin's Manuscripts, "Hanacaraka method for agricultural prophecy," Unpublish, Tasikmalaya, 1982.

[12] T. Kayworth and D. Leidner. "Organizational culture as a knowledge resource," in Handbook on Knowledge Management, Vol. 1: Knowledge Matters, Heidelberg: Springer-Verlag, 2003, pp. 235-252.

[13] Dharmabrata. Lajang Hanatjaraka piwulang matja aksara djawa majar, gampang, Gelissampoerna Djilid 1. GroningenBatavia: JB Wolters Batavia, 1948.

[14] M. Moriyama. Sundanese print culture and modernity in nineteenthcentury West Java. Singapore: NUS Press, 2005.

[15] Widharto. "Tanaman dalam manuskrip Indonesia sebagai bahan rujukan penemuan obat baru." Majalah JUMANTARA Edisi : Vol. 2 No. 2 Oktober, 2011. 